\title{
The Impact of Teacher Feedback Via Google Doc in L2 Learners' Writing
}

\author{
Mohammed Abdullah Alharbi \\ Department of English, College of Education, Majmaah University, \\ Majmaah, Saudi Arabia \\ http://orcid.org/0000-0001-5548-2340 \\ Abdulrahman Nasser Alqefari \\ Department of English, College of Education, Majmaah University \\ Zulfi, Saudi Arabia \\ https://orcid.org/0000-0003-4840-4373
}

\begin{abstract}
Academic writing of assignments is challenging for many undergraduate students of English, and therefore, instructors' written evaluative comments are needed to help students obtain information about their performance in such academic written tasks. As a qualitative case study, this study was carried out on one undergraduate course, specifically on the instructor's written comments on 10 learners' peer academic writing of article reports, how students revise their texts in responding to written comments and how they view such comments and academic writing via Google Docs. The data was collected from the written comments, students' text revisions and a focus group interview. The findings show that the instructor commented on issues and errors at the global and local levels of academic texts directly and indirectly. Quantification of the data illustrated that the instructor provided the five pairs of learners with an overall number of 1440 which targeted 373 (25\%) global issues and 1067 (75\%) local issues in the writing of the five pairs. In terms of direction, $977(68 \%)$ accounted for direct feedback, while $463(32 \%)$ accounted for indirect feedback. Distribution of the feedback received by the learners varied across the five pairs of students. The findings indicate that most of the learners' text revisions were made based on teacher feedback $(1187 / 93 \%)$, while only $95(7 \%)$ revisions were self-made revisions. The thematic analysis of the follow-up interview underlies students' perceived value of teacher feedback in improving their writing, their preference for direct feedback on their writing, their perceived role of Google doc in editing their written assignments. Yet, a few students reported a few restrictions of Google Dos-peer writing and editing. The current study implied that teachers should act as mediators, be aware of the role of feedback in facilitating their students' development of writing and misinterpretation and confusion their feedback can cause to our students in the process of writing revision, and decide what issues their feedback needs to target,
\end{abstract}


focus on what issues actually challenge their learners in writing. Finally, feedback practices should be made innovative through integration of technological tools.

Keywords: academic writing; peer writing; Google Docs-commenting; responses; perception

\section{Introduction}

Academic writing in English is a complex process for learners (Baker, 2019; Saeed et al., 2020). It is even more challenging for those undergraduates joining programs in English as foreign language (EFL) programs (Al Badi, 2015; Alharbi, 2019; Al-Mukdad, 2019; Ariyanti \& Fitriana, 2017; Mahmood et al., 2020; Matsuda $\&$ Tardy, 2007). It becomes necessary if not imperative for instructors and teachers to guide students in writing through effective and constructive feedback. Teacher written feedback is an important task in writing instruction (Bijami, Pandian \& Singh, 2016; Cheng \& Zhang, 2021; Hyland \& Hyland, 2001).

Existed body of research on written feedback focused on error correction either directly or indirectly (Ferris, 2014; Ferris \& Hedgocok, 2005; Lucero, Fernández \& Montanero, 2018) indicating that most teachers' written feedback is provided in the form of error corrections (e.g., removing, adding or substituting erroneous parts) and sometimes in hand written comments on the margins of students' papers (Agbayahoun, 2016; Lee, 2014). Much of this existed literature have contradicting revelations and arguments about students and teachers' preferences of feedback types and strategies (Bailey \& Garner, 2010; Köksal et al., 2018). There are several researchers who argued that teachers should not provide feedback on students' local issues in writing, including grammar and vocabulary, but they should focus their feedback on global issues such as content and organization (Jamalinesari et al., 2015; Truscott, 1996). On the other hand, other researchers argued for the need for focusing teacher feedback on local issues (Chandler, 2003; Irwin, 2017). Other studies have focused on how teachers should formulate and provide their feedback revealing contradicted conclusions and have different arguments about whether feedback should be direct, indirect or both (Chandler, 2003; Ferris, 2006; Liu \& Brown, 2015; Tiyingdee \& Jaroongkhongdach, 2016; William, 2004)

The productivity or efficacy of teacher feedback has attracted many researchers to conduct studies centering on these questions: what should teachers focus on when providing students with feedback on writing? How should teachers provide such feedback to their students? And what could be done to enhance teacher feedback in ESL/EFL writing classes? Still, the contradicting findings and arguments created a big need for more investigations to enrich and enhance understanding of feedback process.

As part of research on enhancing teacher feedback, technology has been defined as an innovation that should be incorporated in ESL/EFL writing classrooms by teachers when providing feedback on their students' writing (Ali, 2016; Lee, 2004). More specifically, Google doc, which is one of the Web 2.0 technological tools, has 
been highly recommended by researchers as an effective tool for teachers in tracing their students' writing (Chu et al., 2011; Gillow-Wiles \& Niess, 2017; Saeed \& Al Qunayeer, 2020) and also providing them with constructive feedback through written comments (Ebadi \& Rahimi, 2017; Hidayat, 2020; Semeraro \& Moore, 2016). However, so far, empirical research that has investigated what and how teachers use Google doc for feedback on their students' writing is still rare.

Unlike surveys and experimental studies that basically focus on predetermined variables and traditional techniques of feedback provision, the current study is a qualitative case study that adopts a holistic approach of data analysis that presents an advantage to account for the particular issues identified in teachers' written feedback. It also contributes to fill some gaps in the existed literature of digital written feedback in general and that of Saudi context in particular by identifying the characteristics of digital written feedback provided by the teachers through Google Docs. The study may also be valuable as it addresses different aspects related to both teachers and learners and use various sources of data to find answers to its questions. It may also contribute to reveal all the possible factors affecting teachers' perceptions and learners' reactions and perceptions about the importance of written feedback and the challenges they may face when revising and providing digital feedback using Google Docs as a technical mean of feedback provision.

Therefore, this study, being motivated by the above issues, arguments and gaps in previous research on teacher feedback on ESL/EFL students' writing, aimed to address the following research questions:

1. What are the issues in EFL students' writing addressed by the instructor through feedback using Google doc?

2. How does the instructor address the various issues in EFL learners' writing using Google doc?

3. To what extent does the feedback help the EFL students in revising their texts via Google doc?

4. How do the EFL learners perceive the instructor's feedback on their writing via Google doc?

\section{Literature Review}

\subsection{Theoretical Views}

The current investigation of teacher feedback and its role in fostering EFL students' attention to issues in writing and enabling them to revise their texts is based on the socio-cultural approach to ESL/EFL teaching and learning. Specifically, the study is based on Vygotsky's (1987) theory and the Activity Theory (AT) which is originated based on Vygotsky's (1978) theory (Leont'ev, 1981). Both theoretical perspectives emphasize the role of mediation in the process of the individual's learning and cognitive development. While Vygotsky's (1978) theory focuses on the role of teachers as mediators in the ESL/EFL classroom contexts, the activity theory focuses on how the context influences teaching and learning practices and activities. In other words, while the first theory has its significant implications for teacher-learner interactions and feedback practices in the ESL/EFL classrooms, particularly writing classrooms, the latter theory has its implications for what shapes and mediates such practices. In discussing teacher 
feedback from the AT, Lee (2014) refers to artifacts as instruments that mediate teacher's feedback practices in writing. Such instruments are also influenced by the knowledge, beliefs and previous experience of the teacher. The author argues for innovative ways to replace or even to be added to conventional teacher feedback practices in the EFL writing classroom. Such conventional practices that merely focus on mere corrections and do not allow students to interpret and diagnose teacher feedback should be innovated in a way that students are provided with sufficient teacher's mediation through comments, highlighting and coding errors so that they can understand their issues in writing and revise it.

\subsection{Teacher Feedback in Writing}

Research on teacher feedback on ESL/EFL writing has focused on the content of feedback in order to identify the major issues and challenges in writing. Regarding this, findings of previous studies seem contradictory. There are several researchers who analyzed the content of teacher feedback on students' writing and found that teacher feedback focuses on local issues in writing, such as grammar, vocabulary and punctuations more than global issues, such as content and organization (Diab, 2015; Ferris, 2006; Junqueira \& Payant, 2015; Mahfoodh, 2017; Mao \& Crosthwaite, 2019; Saliu-Abdulahi et al., 2017). Moreover, teacher feedback on local issues enabled students to detect issues in writing and make substantial text revisions (Chandler, 2003; Kurzer, 2018). Other studies have reported opposite results showing that teacher feedback on local issues tend to be ineffective and deviate learners from focusing on revising their texts globally (Ene \& Upton, 2018; Truscott, 1996). There are also other researchers who advocated arguments supporting the focus of teacher feedback on both local and global issues for both areas are important for enhancing learners' writing (Alkhatib, 2015; Ferris, 2003).

Another aspect of teacher feedback investigated in previous research is construction and delivery of teacher feedback. How teachers construct and deliver their feedback has also been a topic of an interest for several scholars and researchers who have different arguments about whether teacher should address issues in learners' writing directly or indirectly. There is also a body of previous research which has focused on direct and indirect corrective feedback. More recent studies have shown that teachers include a meta-linguistic explanation as a form of direct feedback. For instance, Bitchener and Knoch (2009) reported that three types of teacher's corrective feedback on students' use of the English indefinite article in writing: direct corrections only, direct corrections with oral explanations and direct corrections with written explanations. The three types of feedback were effective for students' revision of their writing. On the other hand, indirect corrective feedback refers to teacher's feedback indicating to a given error in an indirect way (Ferris, 1995; Ferris, 1997; Chandler, 2000). This includes, for instance, coding the error, asking a question, underlying the error or circling the error and so forth. In other words, indirect feedback identifies the error or issue in the written text, but it does not give the student a particular solution/remedy in writing (Bitchener \& Ferris, 2012; Bitchener \& Knoch, 2009; Ferris \& Roberts, 2001). In a study by Tiyingdee and Jaroongkhongdach (2016), the researchers reported that most of the teacher written feedback tended to be provided to the 
students directly. Such finding was justified by the easy nature of direct feedback to be understood by EFL students in revising their writing.

To determine the efficacy or impact of teacher feedback on students' writing, some studies analyzed the subsequent text revisions made by learners in response to teacher feedback. Findings revealed that teacher feedback led to both meaningbased text and form-based text revisions (Hyland, 2003). According to Silver and Lee (2007), advice as a form of teacher feedback was more effective than criticism since it encouraged students to make most of their text revisions. In Terglia's (2009) study, most of the teacher feedback comments leading to students' substantial and successful text revisions are single request comments and comments providing information. Some empirical studies questioned the efficacy of teacher feedback in terms of its level of directness on students' text revisions (Chandler, 2003; Ferris, 2006; Treglia, 2009). The results of both studies supported the role of direct feedback on students' accurate revisions in writing. William (2004) also found that as the teacher used direct suggestions, the case students were able to make successful text revisions, especially at the sentence level. However, the students needed more guidance when the teacher provided indirect feedback. On the other hand, results of some other studies indicate that teacher indirect feedback was more effective than direct corrections in enhancing learners' texts online (Alvarez et al., 2013; Wolsey, 2008).

Studies have also explored students' perception of teacher feedback on their writing. Hyland (2003) reported that most of the case students valued teacher feedback for it helped them to refine their writing in terms of form, including grammar and sentence structure. Other findings revealed that affective engagement of lower-proficiency students with teachers' written corrective feedback was relatively positive, and there was scant awareness at the level of understanding the WCF, especially for the indirect WCF (Zhang \& Hyland, 2018). According to Silver and Lee (2007), students' views on teacher feedback were positive in general, and in particular, they valued advice for advice since it is a moderate form of feedback that reflects teacher's role as a facilitator or mentor and makes students feel free to decide what to revise. On the other hand, their dislike of criticism is due to the explicit nature of this type of feedback that points at students' problems. In a study by Harran (2011), students appreciated teacher feedback for its role in shaping their writing and improving it through drafting and revising. Studies have also found that students tended to prefer indirect feedback, such as coding of errors or labeling them over direct corrections (Ferris et al., 2000). However, according to Ferris and Roberts (2001), students preferred more direct and explicit feedback over indirect and implicit feedback because they felt frustrated with understanding the latter type of feedback.

\subsection{Goggle Doc in Writing}

Google Docs is one of the Web 2.0 digital tools that afforded writing instructors sufficient feedback about their writings. Literature revealed its effectiveness in helping learners read, understand and respond to instructors' written feedback (Alharbi, 2020; Chong, 2019; Mohammed \& AL-Jaberi, 2021; Neumann \& Kopcha, 2019). Several studies on the applications of this technological tool in ESL/EFL 
writing have highlighted its features that make it user-friendly and suitable for learners to edit and revise their work (Ebadi \& Rahimi, 2017; Hedin, 2012; Suwantarathip \& Wichadee, 2014; Woodard \& Babcock, 2014). These studies showed students' positive perception of using Google doc in editing and revising their writing as students feel comfortable in editing their writing by using highlights and refer back to earlier drafts stored in their Google doc pages. They can also access it and do their work regardless of distance and time restrictions as long as their computer devices are connected to the Internet. Moreover, students can edit their writing as in small groups or pairs, thus serving as a useful collaborative environment for writing and editing.

Despite the fact that several studies have explored the potential of Google doc in collaborative writing, these above-mentioned studies have restricted its investigation to the use of Google doc in peer feedback and peer editing. Some few studies have highlighted its potential use for teachers or instructors of writing in mentoring their students' writing (Alsubaie \& Ashuraidah, 2017; Chu et al., 2011; Gillow-Wiles \& Niess, 2017; Saeed \& Al Qunayeer, 2020) and also providing their students with feedback on their writing (Ebadi \& Rahimi, 2017). According to these studies, teachers or instructors of writing at universities can provide their students with feedback through comments embedded into students' Google doc pages, track their work and see their revisions. Yet, there is no comprehensive empirical exploration of teacher feedback via Google doc, particularly in relation to the content of feedback and how teachers formulate their feedback using Google doc. Therefore, the current study attempted to fill up this gap by investigating teacher feedback on students' writing through Google doc.

\section{Methods}

The current study employed a qualitative case study that seeks to explore teacher feedback on EFL students' writing in a Saudi university. It was intended to collect enriching information and obtain an in depth understanding of the process of teacher feedback since this approach allows for an in-depth investigation of the case (Merriam, 1998). As this study also focuses on perception of learners, qualitative methods provide better understanding of how humans or respondents experience and reflect on what has been implemented in a particular area of interest (Bogdan \& Biklen, 2007). According to Dörnyei (2007), numbers can also partially be used in qualitative research and therefore it is not entirely number based statistics. Giving that this study used a qualitative analysis of the data, specifically content analysis, text analysis and thematic analysis, numbers and percentages were used to support arguments and claims and to show variations of the categorized feedback including global, local, direct and indirect.

\subsection{The participants}

As the design of the study was the case study, it focused on 10 undergraduates' academic writing of assignment, article report as part of their formative assessment in an academic writing course in a Saudi university. The participants were 6 females and 4 males enrolled in the course ' Writing 2', in English Department, Majmaah University in Saudi Arabia. The participants have the same cultural and linguistic background as their mother tongue is Arabic and they all 
started studying EFL when they were in grade 4. They were selected in light of their readiness to write essays of different types at the time of data collection for the current study. Table (1) shows the participating students allocated in five pairs (from Pair 1 to Pair 5) along with their assigned pseudonyms which consist of the letters "s and p" standing for the word "student" and "pair" as well as the number of pair to which the students belong. Moreover, the instructor of the course is referred to as "instructor" in the samples of the feedback used in this study. This is to maintain confidentiality and anonymity of the participants.

Table 1: Profile of the Participants

\begin{tabular}{|c|c|}
\hline Pairs' Names & 'tudents' Pseudonym \\
\hline Pair 1 & S1-P1 \& S2-P1 \\
\hline Pair 2 & S1-P2 \& S2-P2 \\
\hline Pair 3 & S1-P3 \& S2-P3 \\
\hline Pair 4 & S1-P4 \& S2-P4 \\
\hline Pair 5 & S1-P5 \& S2-P5 \\
\hline
\end{tabular}

\subsection{The Study Procedure}

The study was conducted in several stages as shown in Figure (1). The first stage, the preparation stage that lasted almost two weeks, and aimed to prepare the EFL students for the writing activities. During this stage, the instructor informed the participants about article reporting writing, feedback and peer editing activities. The stage also covered instruction on how to write article reports and training the students on how to search articles from Google Scholar, ResearchGate or Saudi Digital Library and how to use Google doc for editing their writing. At the end of the stage, the instructor requested the participating students to formulate five pairs, each of which consists of two learners who would work together in the next activities using Google doc.

In the second stage, each pair of students was requested to select three articles on a topic of their own choice in language acquisition and learning and teaching. As each pair selected its articles, the students were asked to formulate the title of their report that reflects the topic of the three articles. Then, they had a discussion in which they planned their reports, especially the general structure. This stage took almost two weeks in which students were involved in reading the three articles and summarizing the main ideas of each article.

The third stage was concerned with engaging the five pairs of students in writing their first draft and it lasted for almost three weeks. The students were given guidance to follow especially for the word limit of report writing (not over 3000 words). During this stage, the five pairs finalized their five first drafts. Following this was the stage of Google doc page creation and uploading the first drafts in the Google doc. The instructor created five Google doc pages and shared each page only with the two students belonging to that pair via emails. Then, each pair had to upload their first draft in their page shared by the instructor.

The fourth stage focused on teacher feedback and students' revision of writing and lasted for almost three weeks. The instructor read the five first drafts and 
provided feedback through written comments. Each pair had to read teacher feedback and responded to it and revise their first draft accordingly. Figure (2) illustrates one Google doc page of Pair 4 where they appeared revising their draft by highlighting their revisions in different fonts based on teacher feedback. This stage seemed a reiterative stage as it involved students in producing multiple drafts stored historically in the Google doc pages.

Preparation: Informing the students of the peer writing and teaching feedback activities, instructing them on report writing, formulating the five pairs of students and training them on using Google doc.

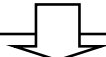

Pre-writing: Involving each pair of students in selecting three articles on a topic of their choice and discussing their plans of first drafts of article reports.

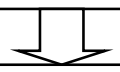

Writing first drafts: Each pair of students wrote the first draft of article reports.

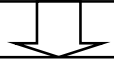

Uploading first drafts in Google Doc: Creating five Google Doc pages, sharing them with the pairs and requesting each pair to upload the first draft.

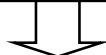

Feedback and Revision: Keeping revising their drafts based on teacher feedback through Google doc.

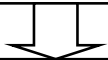

Finalizing and submitting last drafts: Each pair of students had to finalize revising their writing and submit it as the last draft.

Figure 2: Procedures of the data analysis

The last stage focused on students' finalization of their last draft that needed to be submitted to the instructor for their assessment in the course. During this stage, the instructor also kept reading and providing feedback and the students had to refine and edit their draft. However, this stage also involved students' refinement of their writing in terms of formats required for the assessment. This stage lasted for almost two weeks. 


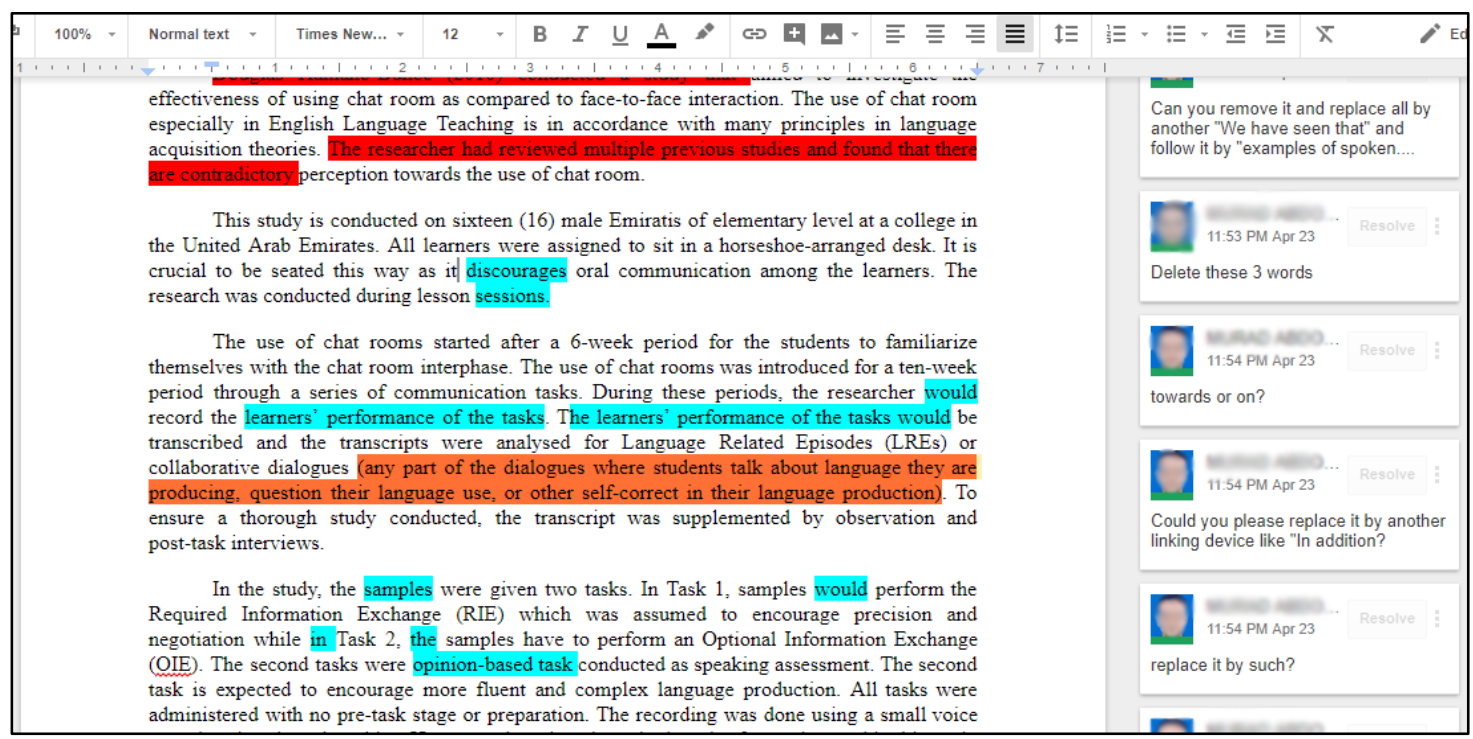

Figure 3: Sample Google-Doc page

\subsection{Data Collection and Data Analysis}

The study used three types of data: teacher feedback in written comments, students' text revisions through Google doc and students' responses to the interview questions (See Appendix). For the first two types of data, they were stored in the Google doc pages and later, they were also organized in file words for each pair of students. For the interview, the participants were interviewed at the end of the semester by the researcher, who is the instructor of the course. The students were asked several questions eliciting their perception of teacher feedback, peer editing or text revisions based on feedback and use of Google doc. the focus-group interviews were conducted (an hour and half) and participants' responses were recorded by the researcher using an audio recorder.

The study used a qualitative analysis of the data, specifically content analysis, text analysis and thematic analysis. However, before actual performance of data analysis, the researcher prepared and organized the data in separate files for each pair of students. Moreover, the recorded interviews were listened to by the researcher several times and then, transcribed. For the instructor's feedback, the researcher used a qualitative content analysis of the foci of each feedback. In coding the feedback, the two coders, who are both researchers in this area, looked at the issue and its aspect of writing the feedback targeted. The following example in the form of a written comment provided by the instructor on the writing of one of the pairs shows how it was coded as "plural forms" since the issue is related to plural nouns: 
Instructor

10:01 AM February 22

Re-open

Selected text:

question.

Collapse

Please, pluralize it better.

Figure 4: Example of teacher's comments

This continued till we finished coding the teacher feedback provided in written comments (overall=1440). Following this was categorizing all issues into global and local issues. The global issues are categorized as content and organization, including coherence, while the local issues are those issues related to grammar, vocabulary and mechanics (Chandler, 2003; Tiyingdee \& Jaroongkhongdach, 2016). The above example feedback was categorized as a local issue, specifically grammar. Then, the feedback was coded once again, but this time, it was coded in terms of its level of defectiveness: direct or indirect. While direct feedback carries either direct corrections and or explicitly stated solutions provided by teacher, indirect feedback provides a hint of an issue in writing, but does not provide a specific solution or remedy to it (Bitchener \& Ferris, 2012; Bitchener \& Knoch, 2009; Ferris \& Roberts, 2001). The above sample feedback, for instance, was coded as direct because it does not only pint at the issue related to the use of accurate noun form, but it also provided the learners with a solution by requesting them to pluralize "question".

For coding the EFL learners' text revisions, we used text analysis of learners' drafts with a focus on the changes highlighted and traced through Google doc based on teacher feedback. First, each change highlighted in the students' texts was coded as a revision and identified in terms of its foci according to the teacher feedback. For instance, the following sentence extracted from the writing of one pair of students carries a change, which is the word "question" as the students pluralized it based on the above feedback. So it was coded as "a word-level revision for accurate plural form", which is later categorized as grammar:

This study could further strengthen or raise questions on the findings of the above articles

From the analysis of the learners' text revisions, we categorized all revisions in accordance with the above categories of issues addressed through feedback: global and local text revisions. The global text revisions refer to changes made by learners to attend to issues and enhance the content and organization of paragraphs and ideas in writing, whereas local text revisions are those changes in texts as a way to correct issues related to grammar, vocabulary and mechanics. Moreover, as we coded the text revisions, we tried to identify if the text revision was made based on teacher direct or not and if it is based on teacher feedback, we specified if it was based on direct or indirect feedback. From this, we identified text revisions based on teacher direct feedback, revisions based on indirect feedback and self-made revisions. 
The students' interviews were also analyzed using a thematic analysis. Thematic analysis is a kind of qualitative analyses which is used to analyze qualitative data to reveal prominent themes (Vaismoradi et al., 2013). Regarding this, the transcripts of the students' interviews were thematically analyzed based on thematic coding that allows the coders to assign students' chunks to codes which constitute up a main them. This was an iterative process by which the students' responses were coded, re-coded and compared till these four main themes emerged which are discussed under the findings related to students' perception of teacher feedback: (1) perceived value of teacher feedback in writing, (2) preference for direct feedback, (3) perceived role of Google doc in editing writing based on teacher feedback and (4) challenges in editing their writing based on teacher feedback through Google doc.

The students' responses to the interview questions were analyzed using a thematic analysis. Regarding this, the two coders read the transcripts of the students' follow-up interviews several times. Then, they continued coding and recoding the data till they defined the themes emergent from the interviews that describe the learners' views on their experiences in the online group discussions. This analysis of such data aimed to answer the third research question. The themes emergent from our analysis are reported in the finding section with examples taken from the students' voices in the interviews.

\section{Findings}

\section{RQ1: What Are the Issues in EFL Students' Writing Addressed by The Instructor Through Feedback Using Google Doc?}

The qualitative content analysis of teacher feedback revealed that the teacher addressed global and local issues. Global issues are those issues related to the content of writing, organization and coherence, whereas local issues are those issues relevant to the use of academic language, including grammar and vocabulary, mechanics and spelling. Each of these main global and local issues is represented by one example of teacher feedback extracted from the Google doc comments (Table 2). Overall, the teacher feedback addressed various sub-issues related to content of students' writing, including the lack of important sections, lacking supporting details, unclearly expressed ideas and arguments as well as irrelevant ideas and details to the topics of writing. The feedback also addressed issues related to the organizations in written texts, specifically the logical follows of ideas as well as cohesion and coherence. Grammar was one of the local issues in writing, including wrong tenses, erroneous sentence structures, forms of words, such as verbs and adjectives as well as wrong use of prepositions. The students also seemed to struggle from accurate vocabulary, particularly words that convey academic registers in article reports. The last type of local issues in writing is represented by mechanics, including punctuations and spelling. 
Table 2. Sample Issues Addressed through Teacher Feedback

\begin{tabular}{|l|l|}
\hline \multicolumn{1}{|c|}{ Patterns } & \multicolumn{1}{c|}{ Samples } \\
\hline Content & $\begin{array}{l}\text { Your report lacks an introductory paragraph about the } \\
\text { topic of the three articles. }\end{array}$ \\
\hline Organization & $\begin{array}{l}\text { Can you just re-order the sentences of this paragraph } \\
\text { instead of jumping from one idea to another? } \\
\text { Please, add because to connect both sentences? Got me? }\end{array}$ \\
\hline Grammar & Shape sure? What is the subject of the sentence? \\
\hline Vocabulary & Change "spoke about" into "highlighted". \\
\hline Mechanics & $\begin{array}{l}\text { No missing punctuation before and after this linking } \\
\text { phrase for contrast here? }\end{array}$ \\
\hline
\end{tabular}

Quantification of teacher feedback shows that the teacher could target an overall number of 1440 issues in the EFL learners' writing via Google doc (Table 3). The EFL learners were challenged by local issues in their academic writing $(1067 / 75 \%)$ and global issues $(373 / 25 \%)$. Moreover, teacher feedback was quantified across the five pairs of students. Overall, Pair 3 and Pair 1 received the highest number of teacher feedback (303/21\% \& 298/21\%, respectively). This is followed by Pair 5 (297/20\%), Pair 2 (286/20\%) and finally Pair 4 (256/18\%).

Table 3: Number and Percentage of Issues in Writing Addressed through Teacher Feedback

\begin{tabular}{|l|l|l|l|l|l|l|}
\hline $\begin{array}{c}\text { Foci of } \\
\text { Feedback }\end{array}$ & \multicolumn{1}{|c|}{ Pair 1 } & \multicolumn{1}{|c|}{ Pair 2 } & \multicolumn{1}{|c|}{ Pair 3 } & Pair 4 & \multicolumn{1}{|c|}{ Pair 5 } & Overall \\
\hline Global & $85(6 \%)$ & $61(4 \%)$ & $91(6 \%)$ & $57(4 \%)$ & $79(5 \%)$ & $373(25 \%)$ \\
\hline Local & $213(15 \%)$ & $225(16 \%)$ & $212(15 \%)$ & $199(14 \%)$ & $218(15 \%)$ & $1067(75 \%)$ \\
\hline Overall & $298(21 \%)$ & $286(20 \%)$ & $303(21 \%)$ & $256(18 \%)$ & $297(20 \%)$ & $1440(100 \%)$ \\
\hline
\end{tabular}

The above results also show variations in the numbers and percentages of feedback received by the five pairs. For the global teacher feedback, Pair 3 received the highest number of this kind of feedback (91/6\%), meaning that most of the global issues addressed by the teacher were found in the written text of Pair 3. Following this are Pair $1(85 / 6 \%)$, Pair $5(79 / 5 \%)$, Pair 2(61/4\%) and Pair 4 $(57 / 4 \%)$. However, for the local issues as addressed by teacher feedback in writing, the order of the five pairs differs as Pair 2 received most of the teacher local feedback $(225 / 16 \%)$, followed by Pair $5(218 / 15 \%)$, and then, Pair 1(213/15\%), Pair 3 (212/15\%) and Pair 4 (199/14\%).

It should be noticed that the percentages of global issues detected in the writing of some pairs as in the case of Pair 3 and Pair 1 and Pair 2 and Pair 4 and local issues as in the case of Pair 1 and Pair 3 and Pair 5 are due to the numbers of issues in the writing of these pairs which are almost near or close to each other.

RQ2: How Does the Instructor Address the Various Issues in EFL Learners' Writing Using Google Doc?

For construction of teacher feedback, findings show that the instructor constructed direct and indirect feedback. In using indirect feedback, the instructor 
did not only select and highlight the part of a given written text via Google doc, but he also provided a comment carrying an explanation of the issue and the solution to it. This is illustrated by Example (1) in Table (4). On the other hand, example (2) demonstrates how the instructor constructed and delivered feedback in an indirect manner by which he neither pointed at a specific issue nor did he give the learners a specific solution to it rather he requested them to re-phrase the entire sentence. The students could respond to the teacher indirect feedback by successfully re-phrasing the sentence.

Table 4: Sample Direct and Indirect Feedback through Google

\begin{tabular}{|l|l|}
\hline Sample direct feedback & \multicolumn{1}{|c|}{ Sample indirect feedback } \\
\hline Instructor & Instructor \\
6:01 PM Apr 29 & 3:05 PM Apr 26 \\
Re-open & Re-open \\
Selected text: & Selected text: \\
The article aims to discover that how bilingualism & The result can be understandable by seeing \\
effects. & the statement that has been written under \\
Collapse & the result section. \\
The sentence does not look academically & Collapse \\
written. Can you just change into "The article & Can you rephrase this sentence in a \\
focuses on the impact of bilingualism"? & better way? \\
Reply & Reply \\
S1-P3 & S2-P1 \\
Selected text: & Selected text: \\
The article focuses on the impact of & The statements of the results of this \\
bilingualism on the reading ability of & article were quite clear. \\
learners. & I did it Dr. \\
How is it now? & $3: 10$ PM Apr 26 \\
7:20 PM Apr 29 & S \\
R & Instructor \\
Instructor & Good now. \\
Great. & $4: 14$ AM Apr 28 \\
8:15 PM Apr 29 & \\
\hline
\end{tabular}

The teacher direct and indirect feedback was calculated overall and its distributions across the five pairs of EFL learners (Table 5). First, most teacher feedback via Google doc tended to be direct $(977 / 68 \%)$, while only the indirect feedback accounted for $(463 / 32 \%)$. Secondly, the distributions of the direct and indirect teacher feedback varied across the five pairs of students as the highest number of direct feedback was provided to Pair 3 (252/17\%), which was followed by Pair 5 (211/15\%), Pair 3 (184/13\%), Pair 2 (169/12\%) and Pair 1 (161/11\%). For the indirect feedback, Pair 1 received the highest number of such feedback from the instructor $(137 / 9 \%)$. The second highest number of indirect feedback was provided to Pair 1 (117/8\%), followed by Pair 5 (86/6\%), Pair $4(72 / 5 \%)$ and the lowest number of feedback (51/4\%) was received by Pair 3 . The varying numbers and percentages of direct and indirect feedback among the five pairs of students 
could underlie their ability to revise their writing with or without much direct scaffolding from the instructor.

Table 5: Number and Percentage of Teacher Direct and Indirect Feedback across the Five Pairs

\begin{tabular}{|l|l|l|l|l|l|l|}
\hline $\begin{array}{c}\text { Foci of } \\
\text { Feedback }\end{array}$ & \multicolumn{1}{|c|}{ Pair 1 } & \multicolumn{1}{c|}{ Pair 2 } & \multicolumn{1}{c|}{ Pair 3 } & \multicolumn{1}{c|}{ Pair 4 } & \multicolumn{1}{c|}{ Pair 5 } & \multicolumn{1}{|c|}{ Overall } \\
\hline Direct & $161(11 \%)$ & $169(12 \%)$ & $252(17 \%)$ & $184(13 \%)$ & $211(15 \%)$ & $977(68 \%)$ \\
\hline Indirect & $137(9 \%)$ & $117(8 \%)$ & $51(4 \%)$ & $72(5 \%)$ & $86(6 \%)$ & $463(32 \%)$ \\
\hline Overall & $298(20 \%)$ & $286(20 \%)$ & $303(21 \%)$ & $256(18 \%)$ & $297(21 \%)$ & $1440(100 \%)$ \\
\hline
\end{tabular}

$R Q$ 3: To what extent does the feedback help the EFL students in revising their texts via Google doc?

The qualitative analysis of learners' text revisions via Google doc shows that the learners revised their texts globally and locally based on teacher feedback. They made global revisions related to content, organization, including coherence and local revision pertinent to grammar, vocabulary and mechanics, each of which is illustrated through an example in Table (6). The learners refined their writing in relation to the content by adding sentences or even full paragraphs, removing unnecessary details in some cases or irrelevant ideas and substituting sentences in order to clearly express their ideas. The sample extracted revised by Pair 5 shows how the students added sentences functioning as introductory paragraphs giving information of each article summarized.

The EFL learners also made revisions related to organizations by moving paragraphs and groups of sentences in order to achieve a logical flow of ideas in their writing (See example 2 by Pair 3). The same example shows how coherence was paid attention by the learners as they added linking devices at phrase and word levels such as "however". The EFL learners also revised the language of their writing, specifically grammar and vocabulary. Their highlighted revisions varied from addition, substitution, removal and even rearrangement of linguistic items in writing. This is seen by the fourth and fifth examples taken from the texts of Pair 1 and Pair 4, respectively. The last example by Pair 1 shows how the learners revised their writing related to the use of mechanics, including punctuations.

Table 6: Sample Text Revisions in Responding to Teacher Feedback

\begin{tabular}{|l|l|}
\hline Patterns of text revisions & \multicolumn{1}{c|}{ Samples } \\
\hline Content & $\begin{array}{l}\text { This is a review of the research article "Managing Mutual } \\
\text { Orientation in the Absence of Physical Copresence: } \\
\text { Multiparty Voice-Based Chat Room Interaction", written } \\
\text { by Christopher Joseph Jenks and Adam Brandt, } \\
\text { published in Discourse Processes in 2013. }\end{array}$ \\
\hline Organization & $\begin{array}{l}\text { If I want to compare the literature review in all three } \\
\text { articles, I would be most confused in article 1 as the } \\
\text { author came up with 3 hypotheses which they had to use } \\
\text { a broad literature to support the problem being } \\
\text { researched. For article 1, it was unclear as the literature }\end{array}$ \\
\hline
\end{tabular}




\begin{tabular}{|l|l|}
\hline & $\begin{array}{l}\text { was a mix of studies that support a particular position, } \\
\text { and those against. In article 2, however, the author } \\
\text { organized literature review in a systematic way where } \\
\text { wide treatment approaches in treating speech-sound } \\
\text { children have been described. Then the researcher } \\
\text { supported this issue with previous studies to prove it as } \\
\text { an important element in the therapeutic success. } \\
\text { In article 1 and 2, the author revealed a gap in existing } \\
\text { research. However, in article 3, the author formulated } \\
\text { two research questions to address the research problem. }\end{array}$ \\
\hline Grammar & $\begin{array}{l}\text { It was unclear as the literature was a mix of studies that } \\
\text { support a particular position, and those against. }\end{array}$ \\
\hline Vocabulary & $\begin{array}{l}\text { In order to-achieve the objective, the researchers } \\
\text { answered the following questions: }\end{array}$ \\
\hline Mechanics & $\begin{array}{l}\text { As argued by Iphofen (2012), students should not feel } \\
\text { obligated to be part of the learning activities if they don't } \\
\text { wish to be. }\end{array}$ \\
\hline
\end{tabular}

Calculation of the learners' text revisions overall and its global and local types as well as across the drafts of the five pairs of students revealed interesting results (Table 7). Overall, the learners made a number of 1282 text revisions, the majority of which were local revisions $(975 / 76 \%)$ on grammar, vocabulary and mechanics. However, they made less global text revisions (307/24\%) on content, organization and coherence. The number and percentages of text revisions made by the learners vary as the highest number of text revisions were made by Pair $1(293 / 23 \%)$, and the second highest number of text revisions were made by Pair 3 and Pair 5 (258 $\& 252$, respectively) with almost similar rates or percentages $(20 \%)$. The last 2 pairs with the lowest numbers of text revisions are Pair $2(243 / 19 \%)$ and Pair 4 (236/18\%). The results also show that Pair 3 made the highest proportion of global text revisions (78/6\%), followed by Pair 1 (73/6\%), Pair 5 (61/5\%), Pair 4 (55/4\%) and Pair $2(40 / 3 \%)$. For the local revisions, the largest proportion of revisions were made by Pair 1 (220/17\%), followed by Pair $2(203 / 16 \%)$, and then, Pair 5 (191/15\%), Pair 4 (181) and Pair 3 (180) with the same percentage of 14\%.

Table 7: Number and Percentage of Learners' Text Revisions

\begin{tabular}{|l|l|l|l|l|l|l|}
\hline $\begin{array}{c}\text { Foci of } \\
\text { Feedback }\end{array}$ & \multicolumn{1}{c|}{ Pair 1 } & \multicolumn{1}{c|}{ Pair 2 } & \multicolumn{1}{c|}{ Pair 3 } & \multicolumn{1}{c|}{ Pair 4 } & \multicolumn{1}{c|}{ Pair 5 } & \multicolumn{1}{|c|}{ Overall } \\
\hline Direct & $161(11 \%)$ & $169(12 \%)$ & $252(17 \%)$ & $184(13 \%)$ & $211(15 \%)$ & $977(68 \%)$ \\
\hline Indirect & $137(9 \%)$ & $117(8 \%)$ & $51(4 \%)$ & $72(5 \%)$ & $86(6 \%)$ & $463(32 \%)$ \\
\hline Overall & $298(20 \%)$ & $286(20 \%)$ & $303(21 \%)$ & $256(18 \%)$ & $297(21 \%)$ & $1440(100 \%)$ \\
\hline
\end{tabular}

The learners' text revisions were also linked to the teacher direct and indirect feedback to determine the efficacy of these two types of feedback in learners' text revisions (Table 8). The results indicate that most of the learners' text revisions were made based on teacher direct feedback (895/70\%). However, only a smaller proportion of texts revisions were made by the EFL learners based on teacher indirect feedback (292/23\%). The remaining number of text revisions $(95 / 7 \%)$ was not made by learners based on teacher feedback but self-made revisions intended to enhance their texts. 
Table 8: Number and Percentage of Text Revisions in Relation to Direct and Indirect Feedback

\begin{tabular}{|l|c|c|c|c|c|c|}
\hline \multicolumn{1}{|c|}{$\begin{array}{c}\text { Foci of } \\
\text { Feedback }\end{array}$} & Pair 1 & Pair 2 & Pair 3 & Pair 4 & Pair 5 & Overall \\
\hline $\begin{array}{l}\text { Based on } \\
\text { direct } \\
\text { feedback }\end{array}$ & $203(16 \%)$ & $174(14 \%)$ & $190(15 \%)$ & $160(12 \%)$ & $168(13 \%)$ & $895(70 \%)$ \\
\hline $\begin{array}{l}\text { Based on } \\
\text { indirect } \\
\text { feedback }\end{array}$ & $70(5 \%)$ & $51(4 \%)$ & $42(3 \%)$ & $58(5 \%)$ & $71(6 \%)$ & $292(23 \%)$ \\
\hline Self-made & $20(2 \%)$ & $18(1 \%)$ & $26(2 \%)$ & $18(1 \%)$ & $13(1 \%)$ & $95(7 \%)$ \\
\hline Overall & $293(23 \%)$ & $243(19 \%)$ & $258(20 \%)$ & $236(18 \%)$ & $252(20 \%)$ & $1282(100 \%)$ \\
\hline
\end{tabular}

The above results show that each pair made a higher number of text revisions based on teacher direct feedback. Moreover, most of text revisions that are triggered by teacher direct feedback were made by Pair 1 (203/16\%), while the least amount of text revisions was made by Pair 4 (160/12\%). Interestingly, Pair 5 made the highest number of text revisions based on teacher indirect feedback $(71 / 6 \%)$, while Pair 3 made the lowest number of text revisions (42/3\%). There are also variations in the number and percentage of text revisions made by learners as self-corrections across the five pairs as Pair 1 scored the highest number of such text revisions $(20 / 2 \%)$, whereas the least proportion of text revisions were made by Pair 1 (13/1\%).

$R Q$ 4: How do the EFL learners perceive the instructor's feedback on their writing via Google doc?

The findings obtained from the thematic analysis of the interviews are interpreted and discussed under four main themes: (1) perceived value of teacher feedback in writing, (2) preference for direct feedback, (3) perceived role of Google doc in editing writing based on teacher feedback and (4) challenges in editing their writing based on teacher feedback through Google doc.

For the students' perception of teacher feedback, most of them showed positive perception of such feedback in writing. For instance, according to S1-P3, "I like receiving feedback. It's really helpful for me in my writing". The voices of participants also indicate that teacher feedback enabled them to know what issues they were struggling from in writing their article reports. As stated by S2-P4 "feedback helped me to see my errors and mistakes, such as the use of articles in English, academic words, and son on in writing". The students also appreciated teacher feedback for it provided them with useful directions on what and how to revise their writing. In this regard, it was stated that "the feedback provided by the instructor in Google doc helped me to edit and revise our writing, especially ideas, flow of ideas and even grammar and punctuations" (S1-P1). The students perceived teacher feedback as an important support for them in improving their writing of article reports. S2-P3 admitted this by pointing out "I liked teacher feedback especially when ah I mean I felt satisfied to see our last draft". It was also interesting that some students pointed at teacher feedback as source of motivation for them in writing. S2-P2 is one of those students who stated 
"Feedback, of course, is important for me because I got confident and motivated to do more in my writing".

An interesting finding is related to students' preference for teacher direct feedback. Most of the students talked about their like for teacher feedback when it is given directly because they understand their issues in writing and revise it accurately. For example, the voice of S1-P1 shows why they like direct feedback rather than indirect feedback. In other words, he stated that "I really like direct feedback because sometimes I cannot understand it when the teacher just points at the error in an indirect manner, but direct feedback, I can know what's wrong with my writing and do revisions correctly.

The findings of the study also highlight students' positive perception of the role of Google doc in editing and revising their writing. Regarding this, they pointed at several features that made Google doc as a valuable tool for them, including collaborative text editing: "It's a good way to read teacher feedback and do editing of writing with my friend at the same time" (S2-P5), anytime and anywhere editing: "Google doc was convenient for me when editing writing while sitting at home" (S2-P1) and visualization and traceability of edits: "Yeah. Google doc helped me to use or I mean to put color as highlights and also I can see the revisions my friend made" (S1-P3).

The last theme inferred from the interviews covers some challenges the students encountered in revising their writing based on teacher feedback via Google doc. Some of them seemed challenged by how to respond to instructor's comments, especially at the start of the revision activities. One of those students is S2-P3, who stated “At first, I didn't know so sometimes I deleted the comments after I made revisions also confused about the many drafts". Others also pointed at the time constraints because they spent much time editing their writing: "Sometimes, you know because we have other courses, so I need to spend more time to edit my writing".

\section{Discussion}

The present study aimed to explore the role of teacher corrective feedback via Google doc on the academic writing of five pairs of EFL learners. Specifically, the study was intended to identify the issues in students' writing addressed by teacher feedback. Interpretation of the findings of the present study from the socio-cultural approach (Leont'ev, 1981; Lee, 2014; Vygotsky, 1978) suggests that teacher feedback plays an important role in mediating learners' understanding of the various global and local issues in writing. Effective feedback is "a key element of the scaffolding provided by the teacher to build learner confidence and the literacy resources to participate in target communities" (Hyland \& Hyland, 2006, p. 83).

The findings of the present study indicate that the instructor of the course writing targeted both types of issues in the EFL learners' writing of article reports: global issues which refer to those issues related to content and organization, including coherence as well as local issues which refer to those issues pertinent to grammar, 
vocabulary and mechanics. This finding supports findings of several previous studies on the content or focus of teacher feedback on students' writing (Chandler, 2003; Conrad \& Goldstein, 1999; Ferris, 2003; Ferris, 2006). Some of these researchers (e.g., Ferris, 2006) argued that teacher feedback should target issues in writing at the local level, whereas others argued that teacher feedback should emphasize learners' global issues in writing. However, the current study is in agreement with what other researchers argued about the focus of teacher feedback (1990; Ferris, 2003). In other words, teachers should focus on both global and local issues in writing because both are important for developing students' writing. The finding is also similar to what was found by Tiyingdee and Jaroongkhongdach (2016) in relation to teacher feedback on content, organization and language. This study also found that teacher feedback on the students' local issues outnumbered feedback on the global issues in writing. Such finding does not suggest that the instructor was more interested in commenting on the local issues of the students' writing, but most of the issues and errors made by the EFL learners were local issues.

Since the level of direction is important for teacher feedback, in this study, teacher feedback was analyzed once again in terms of whether it is direct or indirect. The findings showed that the instructor formulated and provided the EFL learners feedback on writing directly and indirectly. In line with several previous studies (Chandler, 2000; Ferris, 1995, 1997 ), this study indicates that the instructor of the course provided direct feedback by highlighting the part of the written text carrying the issue or error and offering them the accurate solution or remedy (Bitchener \& Ferris, 2012; Chandler, 2000; Ferris, 1995; Ferris, 1997;2006; Ferris \& Roberts, 2001). The current study also contributes to these studies on teacher direct feedback by finding that the instructor of the course no longer used the traditional way of providing direct feedback through removal or addition or even substitution of the erroneous parts of the texts. However, all direct feedback was provided through written comments which give the learners the freedom to incorporate or not to integrate such suggestions in their text revisions. This also corroborates Bitchener's and Knoch's (2009) study in the sense that direct feedback can be offered through explanations rather than direct mere corrections of students' errors in writing.

In this study, the instructor provided more direct feedback than indirect feedback on their writing, which supports previous studies (Chandler, 2003; Ferris, 2006; Tiyingdee \& Jaroongkhongdach, 2016; William, 2004). This can be justified by the easiness of such feedback for students, the direct nature of such feedback that allows students to carry on successful text revisions and the explanations of their issues carried in such direct feedback. Moreover, in the instructor's lower frequency of providing indirect feedback could be due to some students' misinterpretation of such feedback, which consequently disabled them to make successful remedies to such issues and effective text revisions. Therefore, the instructor resorted to more direct feedback.

In this study, the extent to which the students revised their writing based on teacher feedback in general and in particular, direct and indirect feedback was 
determined. Overall, most text revisions were based on the teacher feedback. Such finding implying that most of the teacher feedback was accepted and incorporated by the EFL learners in editing through Google doc corroborates findings of some studies (Hyland, 1998; Hyland, 2003) regardless of the different taxonomies used in analyzing learners' text revisions. In this study, the learners attended to content, organization, grammar, vocabulary and mechanics. However, they made a higher number local of text revisions than global text revisions, which is consistent with the teacher's higher number of local feedback than global feedback. Moreover, direct feedback was conducive to most text revisions made by the learners. This supports the argument advocated by some researches for the efficacy of teacher direct feedback (Chandler, 2003; Ferris, 2006; William, 2004), while it contradicts what was reported by few other researchers (Alvarez et al., 2013; Wolsey, 2008). Here, it should be noted what is effective in one study in a particular context may not be the same in another study in a different context.

In this study, the students' voices in the interviews contribute to our understanding of the value of teacher feedback as scaffolding and guidance in writing. The students valued teacher feedback for it allowed them to understand their issues in writing and revise their written texts successfully. Their voices also support the efficacy of teacher direct feedback as they preferred direct feedback since it is easy to understand and revise their texts. Several studies have documented learners' positive views of teacher feedback in writing (Enginarlar, 1993; Harran, 2011; Hyland, 2003; Silver \& Lee, 2007) and their preference for direct feedback (Ferris \& Roberts, 2001) or indirect feedback in other studies (Ferris et al., 2000).

Being central to research questions, the findings indicate that Google doc is a valuable tool for teacher feedback and students' text revisions since it allowed them to read the instructor's feedback, see his highlights of the parts of writing and also to track their revisions and learning. It was revealed that Google Docs facilitated students' revisions and enabled them to move paragraphs and sentences to reorganize their writings. These results coincided with previous findings that support the potential of Google doc in teacher feedback (Alharbi, 2020; Chong, 2019; Ebadi \& Rahimi, 2017; Khalil, 2018; Mohammed \& AL-Jaberi, 2021; Neumann \& Kopcha, 2019). The facilitative effect of Google Docs is representative in enabling the teacher to communicate and elaborate enough feedback to the students in a click of a button, and empowering the students to access their work from a computer or mobile phone anywhere and anytime (Khalil, 2018). This s very helpful to the case of a large class with many tasks requiring written feedback (Tamimi, 2017; Woodrich \& Fan, 2017).

Despite the encouraging findings, the students' active involvement in writing was challenged by their first-time experience in using Google doc for editing in addition to time restrictions as well as observed misinterpretation and frustration with indirect feedback. 


\section{Conclusion and Implications}

There are several implications for theory, pedagogy and research on ESL/EFL writing underlined by the findings of the current study. For the theoretical implications, the findings of the study indicate that teacher feedback is a type of mediation or scaffolding that guides learners to understand their issues and errors in writing and assists them to revise their texts. Moreover, from the sociocultural approach to language learning, particularly writing, such mediation does not take place in a vacuum but rather it is constructed and embedded in a sociocultural context and shaped by teachers' and learners' beliefs and perception.

For the pedagogical implications, the current study was motivated by the traditional teacher feedback practices in writing classrooms, especially in the EFL context where teachers act as direct editors of learners' errors in writing. In this regard, teachers should act as mediators who guide their learners in writing thorough comments. They should also be aware of the role of feedback in facilitating their students' development of writing.

Although the essence of teacher feedback is to help students understand their issues, especially global issues, teachers should decide what issues their feedback needs to target and they should focus on what issues actually challenge their learners in writing even if most of these issues tend to be local issues such as grammar, vocabulary and mechanics.

As writing instructors, we are increasingly aware of the importance of feedback in learners' development of writing. However, as we comment on students' writing, we should also be aware of misinterpretation and confusion our feedback can cause to our students in the process of writing revision. In other words, the way instructors formulate their feedback can affect students' text revisions and improvement of their written texts. Therefore, instructors should decide how to formulate and provide their feedback to students-directly or indirectly or both.

Feedback practices should be made innovative through integration of technological tools. This study indicates that Google doc is one of these technological tools that facilitate teacher feedback and peer editing of writing. The application of Google doc in such practices is promising and encouraging since it helps teachers to highlight students' errors and comment on their writing and at the same time, assists learners to read and reflect on, understand the issues in their writing and successfully use such feedback in revising their texts.

\section{Limitations and Future Research}

In conclusion, although the findings of the current study are encouraging, several limitations that may have affected the findings should be addressed for future research. First, the study focused on a small number of students that constitute only five pairs. Therefore, future research can replicate this study by focusing on a large number of students. This study was exclusive to exploring the issues in writing as addressed by teacher feedback and its different types overall and across the five pairs rather than in each individual's writing. Future studies should also look at this by tracing each individual's issues and text revisions in each pair of 
students. Technology such as Google doc can allow instructors and teachers to trace each individual learner's actions as responses to feedback. While the findings of the study provide evidence on the teacher's feedback on the students' writing as illustrated by the text revisions they made to their drafts, the study did not incorporate a measure of first drafts and final drafts. Therefore, this can be potential for future researchers who are interested in measuring the impact of teacher feedback on students' writing through scoring rubrics. Future research may explore how various technological tools used for teacher feedback on writing affect the extent to which such feedback is incorporated by learners in revising their writing.

\section{References}

Agbayahoun, J. P. (2016). Teacher Written Feedback on Student Writing: Teachers' and Learners' Perspectives. Theory $\mathcal{E}$ Practice in Language Studies, 6(10). https://doi.org/10.17507/tpls.0610.01

Al Badi, I. A. H. (2015). Academic writing difficulties of ESL learners. In The 2015 WEI international academic conference proceedings, 1(1), 65-78.

Alharbi, M. A. (2019). Saudi Arabia EFL university students' voice on challenges and solution in learning academic writing. Indonesian Journal of Applied Linguistics, 8(3), 576-587. https://doi.org/10.17509/ijal.v8i3.15276

Alharbi, M. A. (2020). Exploring the potential of Google Doc in facilitating innovative teaching and learning practices in an EFL writing course. Innovation in Language Learning and Teaching, 14(3), 227-242. https:// doi.org/10.1080/17501229.2019.1572157

Ali, A. D. (2016). Effectiveness of Using Screencast Feedback on EFL Students' Writing and Perception. English Language Teaching, 9(8), 106-121. https://doi.org/10.5539/elt.v9n8p106

Alkhatib, N. (2015). Written corrective feedback at a Saudi university: English language teachers' beliefs, students' preferences, and teachers' practices. [Doctoral dissertation, University of Essex].

Al-Mukdad, S. (2019). Investigating English academic writing problems encountered by Arab International University students. Theory and Practice in Language Studies, 9(3), 300-306. https://doi.org/10.17507/tpls.0903.07

Alsubaie, J., \& Ashuraidah, A. (2017). Exploring Writing Individually and Collaboratively Using Google Docs in EFL Contexts. English Language Teaching, 10(10), 10-30. https://doi.org/10.5539/elt.v10n10p10

Alvarez, I., Espasa, A., \& Guasch, T. (2012). The value of feedback in improving collaborative writing assignments in an online learning environment. Studies in Higher Education, 37(4), 387-400. https:/ / doi.org/10.1080/03075079.2010.510182

Ariyanti, A., \& Fitriana, R. (2017). EFL students' difficulties and needs in essay writing. Advances in Social Science, Education and Humanities Research (ASSEHR), 158, 111-121. https:// doi.org/10.2991/ictte-17.2017.4

Bailey, R., \& Garner, M. (2010). Is the feedback in higher education assessment worth the paper it is written on? Teachers' reflections on their practices. Teaching in higher education, 15(2), 187-198. https://doi.org/10.1080/13562511003620019

Baker, J. (2019). Writing about the writing center in the Asian context: Exploring the mis/match between the reading levels of self-access materials and the students who visit the center. The Asian ESP Journal, 15(3), 256-285. 
Bijami, M., Pandian, A., \& Singh, M. K. M. (2016). The Relationship between teacher's written feedback and student's' writing performance: Sociocultural perspective. International Journal of Education and Literacy Studies, 4(1), 59-66.

Bitchener, J., \& Ferris, D. R. (2012). Written corrective feedback in second language acquisition and writing. Routledge.

Bitchener, J., \& Knoch, U. (2009). The value of written corrective feedback for migrant and international students. Language teaching research, 12(3), 409-431. https:// doi.org/10.1177/1362168808089924

Bogdan, R. C. \& Biklen, S. K. (2007). Research for education: An introduction to theories and methods. New York: Pearson.

Chandler, J. (2000). The efficacy of error correction for improvement in the accuracy of L2 student writing. Paper presented at the AAAL conference, Vancouver, B. C.

Chandler, J. (2003). The efficacy of various kinds of error feedback for improvement in the accuracy and fluency of L2 student writing. Journal of Second Language Writing, 12, 267-296. https://doi.org/10.1016/s1060-3743(03)00038-9

Cheng, X., \& Zhang, L. J. (2021). Teacher written feedback on English as a foreign language learners' writing: Examining native and nonnative English-speaking teachers' practices in feedback provision. Frontiers in Psychology, 12. https:// doi.org/10.3389/fpsyg.2021.629921

Chong, S. W. (2019). College students' perception of e-feedback: a grounded theory perspective. Assessment \& Evaluation in Higher Education, 44(7), 1090-1105. https:// doi.org/10.1080/02602938.2019.1572067

Chu, S., Kennedy, D., \& Mak, M. (2009). 'MediaWiki and Google Docs as online collaborative tools for group project co-construction'. In Proceedings of the International Conference on Knowledge Management, (pp. 1-14). Hong Kong. December, 3-4.

Conrad, S. M., \& Goldstein, L. M. (1999). ESL student revision after teacher-written comments: Text, contexts, and individuals. Journal of second language writing, 8(2), 147-179. https:/ / doi.org/10.1016/s1060-3743(99)80126-x

Diab, N. M. (2015). Effectiveness of written corrective feedback: Does type of error and type of correction matter? Assessing Writing, 24, 16-34.

Ebadi, S., \& Rahimi, M. (2017). Exploring the impact of online peer-editing using Google Docs on EFL learners' academic writing skills: A mixed methods study. Computer Assisted Language Learning, 30(8), 787-815. https://doi.org/10.1080/09588221.2017.1363056

Ene, E., \& Upton, T. A. (2018). Synchronous and asynchronous teacher electronic feedback and learner uptake in ESL composition. Journal of Second Language Writing, 41, 113. https://doi.org/10.1016/j.jslw.2018.05.005

Enginarlar, H. (1993). Student response to teacher feedback in EFL writing. System, 21(2), 193-204. https://doi.org/10.1016/0346-251x(93)90041-e

Ferris, D. (2006). Does error feedback help student writers? New evidence on the shortand long-term effects of written error correction. In K. Hylangd \& F. Hyland (Eds.), Feedback in second language writing (pp. 81-104). Cambridge: Cambridge University Press.

Ferris, D. R. (1995). Student reactions to teacher response in multiple-draft composition classrooms. TESOL quarterly, 29(1), 33-53. https:// doi.org/10.2307/3587804

Ferris, D. R. (1997). The influence of teacher commentary on student revision. Tesol Quarterly, 31(2), 315-339.

Ferris, D. R. (2014). Responding to student writing: Teachers' philosophies and practices. Assessing Writing, 19, 6-23. 
Ferris, D. R., \& Hedgcock, J. (2013). Teaching L2 composition: Purpose, process, and practice. Routledge.

Ferris, D. R., Chaney, S. J., Komura, K., Roberts, B. J., \& McKee, S. (2000). Perspectives, problems \& practices in treating written error. In colloquium presented at International TESOL Convention, Vancouver, BC.

Ferris, D., \& Roberts, B. (2001). Error feedback in L2 writing classes: How explicit does it need to be?. Journal of second language writing, 10(3), 161-184.

Gillow-Wiles, H., \& Niess, M. L. (2015). Engaging Google Docs to Support Collaboration and Reflection in Online Teacher Education. In Handbook of research on teacher education in the digital age (pp. 635-662). IGI Global.

Harran, M. (2011). What higher education students do with teacher feedback: Feedbackpractice implications. Southern African Linguistics and Applied Language Studies, 29(4), 419-434. https:/ / doi.org/10.2989/16073614.2011.651941

Hedin, B. (2012). Peer feedback in academic writing using Google Docs. In Proceedings of LTHs 7: ePedagogiska Inspirations konferens, (pp. 1-3). Lund.

Hidayat, F. (2020). Exploring students' view of using Google Docs in writing class. Journal of English Education and Teaching, 4(2), 184-194. https://doi.org/10.33369/jeet.4.2.184-194

Hyland, F. (1998). The impact of teacher written feedback on individual writers. Journal of second language writing, 7(3), 255-286.

Hyland, F. (2003). Focusing on form: Student engagement with teacher feedback. System, 31(2), 217-230. https:// doi.org/10.1016/s0346-251x(03)00021-6

Hyland, F., \& Hyland, K. (2001). Sugaring the pill: Praise and criticism in written feedback. Journal of second language writing, 10(3), 185-212. https://doi.org/10.5040/9781350037939.0036

Hyland, K., \& Hyland, F. (2006). Interpersonal aspects of response: constructing and interpreting teacher written feedback. In Feedback in Second Language Writing: Contexts and Issues (pp. 206-224). Cambridge: Cambridge University Press. https://doi.org/10.1017/cbo9781139524742.013

Irwin, B. (2017). Written Corrective Feedback: Student Preferences and Teacher Feedback Practices. IAFOR Journal of Language Learning, 3(2), 35-58. https://doi.org/10.22492/ijll.3.2.02

Jamalinesari, A., Rahimi, F., Gowhary, H., \& Azizifar, A. (2015). The effects of teacherwritten direct vs. indirect feedback on students' writing. Procedia-Social and Behavioral Sciences, 192, 116-123. https://doi.org/10.1016/j.sbspro.2015.06.018

Junqueira, L., \& Payant, C. (2015). "I just want to do it right, but it's so hard": A novice teacher's written feedback beliefs and practices. Journal of Second Language Writing, 27, 19-36. https:// doi.org/10.1016/j.jslw.2014.11.001

Khalil, Z. M. (2018). EFL students' perceptions towards using Google Docs and Google Classroom as online collaborative tools in learning grammar. Applied Linguistics Research Journal, 2(2), 33-48.

Köksal, D., Özdemir, E., Tercan, G., Süleyman, G. Ü. N., \& BILGİN, E. (2018). The relationship between teachers' written feedback preferences, self-efficacy beliefs and burnout levels. Journal of Language and Linguistic Studies, 14(4), 316-327.

Kurzer, K. (2018). Dynamic written corrective feedback in developmental multilingual writing classes. TESOL quarterly, 52(1), 5-33. https:// doi.org/10.1002/tesq.366

Lee, I. (2004). Error correction in L2 secondary writing classrooms: The case of Hong Kong. Journal of Second Language Writing, 13(4), 285-312. https://doi.org/10.1016/j.jslw.2004.08.001 
Lee, I. (2014). Revisiting teacher feedback in EFL writing from sociocultural perspectives. Tesol Quarterly, 48(1), 201-213. https:// doi.org/10.1002/tesq.153

Leont'ev, A. A. (1981). Psychology and the language learning process. Pergamon.

Liu, Q., \& Brown, D. (2015). Methodological synthesis of research on the effectiveness of corrective feedback in L2 writing. Journal of Second Language Writing, 30, 66-81. https:// doi.org/10.1016/j.jslw.2015.08.011

Mahfoodh, O. H. A. (2017). "I feel disappointed": EFL university students' emotional responses towards teacher written feedback. Assessing Writing, 31, 53-72. https://doi.org/10.1016/j.asw.2016.07.001

Mahmood, R., Shah, A.H. \& Alam, I. (2020). The Impact of L1 on L2 in Academic English Writing: A Multilingual Dilemma of Pakistani Students. English for Specific Purposes, 16(5), 67-80.

Mao, S. S., \& Crosthwaite, P. (2019). Investigating written corrective feedback:(Mis) alignment of teachers' beliefs and practice. Journal of Second Language Writing, 45, 46-60. https://doi.org/10.1016/j.jslw.2019.05.004

Matsuda, P. K., \& Tardy, C. M. (2007). Voice in academic writing: The rhetorical construction of author identity in blind manuscript review. English for Specific Purposes, 26(2), 235-249. https://doi.org/10.1016/j.esp.2006.10.001

Merriam, S. B. (1998). Qualitative Research and Case Study Applications in Education. Revised and Expanded from" Case Study Research in Education.". Jossey-Bass Publishers, 350 Sansome St, San Francisco, CA 94104.

Mohammed, M. A. S., \& AL-Jaberi, M. A. (2021). Google Docs or Microsoft Word? Master's students' engagement with instructor written feedback on academic writing in a cross-cultural setting. Computers and Composition, 62, 102672.

Neumann, K. L., \& Kopcha, T. J. (2019). Using Google Docs for peer-then-teacher review on middle school students' writing. Computers and Composition, 54, 102524. https://doi.org/10.1016/j.compcom.2019.102524

Saeed, M. A., \& Al Qunayeer, H. S. (2020). Exploring teacher interactive e-feedback on students' writing through Google Docs: factors promoting interactivity and potential for learning. The Language Learning Journal, 1-18. https://doi.org/10.1080/09571736.2020.1786711

Saeed, M. A., Al-Ahdal, A. A. \& Al Qunayeer, H. S. (2020). Integrating research proposal writing into a postgraduate research method course: what does it tell us? International Journal of Research $\mathcal{E}$ Method in Education, 1-16. https:// doi.org/10.1080/1743727x.2020.1777963

Saliu-Abdulahi, D., Hellekjær, G. O., \& Hertzberg, F. (2017). Teachers' (formative) feedback practices in EFL writing classes in Norway. Journal of Response to Writing, 3(1), 31-55.

Semeraro, J., \& Moore, N. S. (2016), "The Use of Google Docs Technology to Support Peer Revision". In Writing Instruction to Support Literacy Success (Literacy Research, Practice and Evaluation, Vol. 7, pp. 203-220), Emerald Group Publishing Limited, Bingley. https://doi.org/10.1108/S2048-045820160000007013

Silver, R., \& Lee, S. (2007). What does it take to make a change? Teacher feedback and student revisions. English Teaching: Practice and Critique, 6(1), 25-49.

Suwantarathip, O., \& Wichadee, S. (2014). The effects of collaborative writing activity using Google Docs on students' writing abilities. Turkish Online Journal of Educational Technology, 13(2), 148-156.

Tamimi, M. H. (2017). Integrating Web 2.0 technologies in learning: Using Facebook group and BYKI in English language courses. International Journal of Arabic-English Studies, 17, 85-108. 
Tiyingdee, A., \& Jaroongkhongdach, W. (2016, May). Written comments on drafts of an independent study: A case study. In The $7^{\text {th }}$ International Conference on Language and Communication (p. 17). Osaka University, Japan.

Treglia, M. O. (2009). Teacher-written commentary in college writing composition: How does it impact student revisions? Composition Studies, 37(1), 67-86.

Truscott, J. (1996). The case against grammar correction in L2 writing classes. Language learning, 46(2), 327-369. https:// doi.org/10.1111/j.1467-1770.1996.tb01238.x

Vaismoradi, M., Turunen, H., \& Bondas, T. (2013). Content analysis and thematic analysis: Implications for conducting a qualitative descriptive study. Nursing $\mathcal{E}$ health sciences, 15(3), 398-405. https://doi.org/10.1111/nhs.12048

Vygotsky, L. (1978). Mind in society: The development of higher psychological processes. Cambridge, MA: Harvard University Press.

Wolsey, T. (2008). Efficacy of instructor feedback on written work in an online program. International Journal on E-Learning, 7(2), 311-329.

Woodard, R., \& Babcock, A. (2014). Designing Writing Tasks in Google Docs that Encourage Conversation: An Inquiry into Feedback and Revision. In Handbook of Research on Digital Tools for Writing Instruction in K-12 Settings (pp. 1-29). IGI Global. https://doi.org/10.4018/978-1-4666-5982-7.ch001

Woodrich, M., \& Fan, Y. (2017). Google Docs as a tool for collaborative writing in the middle school classroom. Journal of Information Technology Education: Research, 16, 391-410. https://doi.org/10.28945/3870

Zhang, Z. V., \& Hyland, K. (2018). Student engagement with teacher and automated feedback on L2 writing. Assessing Writing, 36, 90-102. https://doi.org/10.1016/j.asw.2018.02.004

\section{Appendix 1: Focus-group Interview Questions}

1. What do you think of teacher feedback on your writing?

2. What other aspects about teacher feedback via Google doc that you found valuable for your writing improvement? Why do you think so?

3. Which do you prefer teacher direct feedback or indirect feedback?

4. What features of Google doc you liked more that helped you in revising your writing based on teacher feedback?

5. Any challenges you might have encountered editing your writing via Google doc based on teacher feedback? Explain them. 